\title{
Precision Analysis of Polymer Rheology by Simultaneous Measurement of Viscoelasticity and Birefringence
}

\author{
Tadashi INOUE* \\ * Department of Macromolecular Science, Graduate School of Science, Osaka University, \\ 1-1 Machikaneyama-cho, Toyonaka, Osaka 560-0043, Japan
}

\begin{abstract}
Recent progress of molecular rheology for various polymeric systems by a rheo-optical method using simultaneous measurements of stress and birefringence is briefly reviewed. The advantage of the method is that the stress can be disassembled into its components following the birefringence response. The scope of this review is to elucidate the significance of the viscoelastic segment and also to extend the stress-optical rule to inhomogeneous systems. Firstly, effects of highly branched structures on the viscoelastic segment size is examined with bottle-brush type poly(macromonomer) and highly crosslinked thermoset resins. These studies indicate the importance of internal motions of the viscoelastic segments such as bending and tension modes in addition to the reorientation mode of the segments. These modes can be separately estimated with the aid of the rheo-optical measurements. The estimation of the bending mode is particularly important for the relaxation dynamics of tightly entangled systems of semiflexible polymers. Secondly, the extension of the stress-optical rule for inhomogeneous systems is discussed. In these systems, the concept of phase stresses and strains is quite important to understand their molecular rheology, and the stresses can be estimated from the rheo-optical measurements.

Key Words: Flow birefringence / Polymer dynamics / Stress-optical rule / Modified stress-optical rule
\end{abstract}

\section{粘弾性と複屈折の同時測定による高分子レオロジーの精密解析}

\author{
井上 正志*
}

(原稿受理：2019 年 9 月 15 日)

\section{1. 緒 言}

レオロジーは, 応力と歪みの関係を調べる科学であり，両 者の関係を記述する構成方程式を求めることが本来の目的で あるが，レオロジーをミクロなモデルを用いて説明する立場 を分子レオロジー（Molecular Rheology）と言う。筆者が初め てこの言葉を意識したのは, 所属する研究室名が材料物性基 礎研究部門から分子レオロジーに変わった 1993 年と記憶して いる. ミクロなモデルを用いて数式として記述するためには, 通常は統計力学の助けが必要となり, モデル構築のためには 変形による内部構造変化に関する知見や応力表式を知ること が不可欠であるが, 力学測定からこれらの情報を得ることは 容易ではない。 このため, 力学測定と同時に, 複屈折, 赤外 二色性, 各種散乱法を組み合わせる手法が開発された。これ らの方法の中で, 複屈折は応力との相関が強くレオロジー研 究に適している。

物質にひずみを加えると応力が発生し, 複屈折が観測され る.ゴム状物質の場合, このひずみ誘起による複屈折は, 応 力光学則 $(\mathrm{SOR})$ を用いて応力と関係づけることができる ${ }^{1)}$. $\mathrm{SOR}$ は, 屈折率テンソルの異方性成分 $\hat{\mathbf{n}}(t)$ と応力テンソルの

*大阪大学大学院理学研究科

干 560-0043 豊中市待兼山町 1-1

E-mail: tadashi@chem.sci.osaka-u.ac.jp, Tel: +81-6-6850-5464
異方性成分 $\hat{\boldsymbol{\sigma}}(t)$ を用いて，次式のように書ける.

$$
\hat{\mathbf{n}}(t)=C \hat{\boldsymbol{\sigma}}(t)
$$

ここで, $t$ は時間, $C$ は応力光学係数と呼ばれる定数である. 一般に複屈折 $\Delta n$ は, 屈折率テンソルの主值の差を表し, 伸長 変形の場合, SOR は複屈折と応力が比例することを表し、ゴ ム状物質であれば容易に $C$ を測定することができる。 $C$ はセ グメントの分極率の異方性によって決まるため, 高分子種に よって異なる值になる，歴史的には，Cの值から高分子の局所 形態に関する研究が行われた ${ }^{2)}$. レオロジーの分野では, 通常 の力学測定では測定が難しい法線応力差などの測定に SOR は 利用された ${ }^{1)}$. 分子論的には, SOR はゴム状物質の応力と複屈 折がともにセグメントの配向により生じることを示す. Rouse 模型や管模型などの高分子レオロジーの分子理論では, SOR を用いて鎖の形態（配向）から応力を計算する ${ }^{3)}$.

変形様式として角振動数 $\omega$ の振動ひずみ $\epsilon^{*}(\omega)$ を用いる伸 長変形を考えると, SOR は応力 $\sigma_{\mathrm{T}}^{*}(\omega)$ から計算される複素ヤ ング率 $E^{*}(\omega) \equiv \sigma_{\mathrm{T}}^{*} / \epsilon^{*}$ と動的複屈折 $\Delta n^{*}(\omega)$ をひずみで割った 複素ひずみ光学係数 $O^{*}(\omega) \equiv \Delta n^{*} / \epsilon^{*}$ を用いて, 次式のように 書くことができる. 


$$
O^{*}(\omega)=C E^{*}(\omega)
$$

ずり変形の場合には， $E^{*}$ と $O^{*}$ をそれぞれ複素ずり弾性率 $G^{*}(\omega)$ と複素ずりひずみ光学係数 $K^{*}(\omega)$ に読み替えればよい. ガラス転移領域やガラス状領域では SOR は成立せず，ポリ スチレンなどの高分子では複屈折の符号の反転も観測される. この結果は, これらの領域ではセグメントの配向由来の応力 に加えて, 別の応力の成分が存在するためと考えることがで きる. 別の応力成分はガラス転移領域で顕著になることから, 我々は高分子のバルク状態ではセグメントの配向（添字 R）に

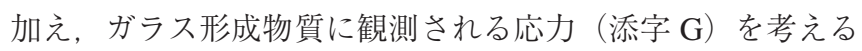
モデル (修正応力光学則, MSOR）を提唱した ${ }^{4)}$. 伸長変形 でのMSORは，次式のように表すことができる．

$$
\begin{aligned}
& E^{*}(\omega)=E_{\mathrm{R}}^{*}(\omega)+E_{\mathrm{G}}^{*}(\omega) \\
& O^{*}(\omega)=C_{\mathrm{R}} E_{\mathrm{R}}^{*}(\omega)+C_{\mathrm{G}} E_{\mathrm{G}}^{*}(\omega)
\end{aligned}
$$

二つの係数が既知であれば, この連立方程式を解いて $E_{\mathrm{R}}^{*}(\omega)$ と $E_{\mathrm{G}}^{*}(\omega)$ を定量的に求めることができる. ちなみにポリスチ レンオリゴマーの弾性率を測定すると G 成分と一致し, G 成 分がガラス性由来で $\mathrm{R}$ 成分が高分子性由来と考えることは, まったく妥当なものと思われた，MSORは，意外にも多くの 高分子で成立し, ガラス転移領域での時間温度換算則の破れ など, 無定形高分子の粘弾性の未解決問題を説明することが できた ${ }^{5)}$ 。さらに, 配向応力のずり弾性率の高周波数（短時 間) 極限 $E_{\mathrm{R}}^{*}(\infty)$ から粘弾性セグメントのサイズという新し いパラメーターを評価できるようになった。一方で，ガラス 転移領域の粘弾性緩和を 2 成分に分離するのは, 単純すぎる という意見を頂いた，また，MSOR では応力の加成性を基本 とするが，ひずみの加成性で考えるべきだとう批判も頂戴し た ${ }^{6)}$. 本稿では, 新しい高分子系での複屈折測定を用いた分 子レオロジー解析の紹介に加えて, こうした指摘や粘弾性セ グメントの意義について考えてみたい.

\section{2. 斜光法によるずり型複屈折測定装置}

2007 年に, 京都大学化学研究所から大阪大学に異動する機 会をいただいた。大阪大学では, ずり型の複屈折測定装置を 新たに開発した ${ }^{7,8)}$. ずり変形ではずり応力の測定が肝要と なるが, ずり応力に相当する複屈折を測るためには, ずり流 動の渦軸に沿って光を入れる必要がある. しかしながら, こ の方法では試料の表面が自由界面となり, 湾曲した表面での 屈折等により光をまっすぐ通す作業が煩雑になる。このため, Fig. 1 に示す斜光法を用いた装置を新たに開発した。 この方法 では，2枚のスライドガラスの間に試料を挟み，上下のガラ スを通るように，光を斜めに入射する．ガラスに対して垂直 に光を入射させると, 第 3 法線応力差に相当する複屈折成分 のみしか測定できないが，光を傾けることによってずり成分 の検出が可能になる。この斜光系では, 第 3 法線応力差成分 とずり成分が混ざった信号が得られるため，一般的に両者を 分離するためには，2 本目の光軸系を加える必要がある。例 えば，垂直に入射して第 3 法線応力差成分を求めれば，斜光 法による結果からずり成分を求めることができる。しかしな

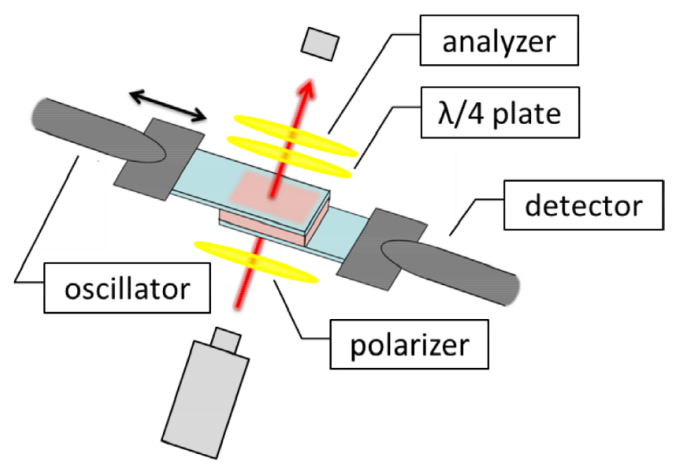

Fig. 1 Illustration of the device for simultaneous measurement of dynamic birefringence and dynamic viscoelasticity by oblique light method.

がら，動的測定の場合には振動変形に対する周波数応答性の 違いから，両者を分離することが可能である．開発した装置 は，この原理に基づくものである，異動前の化学研究所では 伸長型の装置を用いて固体を中心とした研究を行ったが，ず り型の装置の開発により流動域の測定が可能になり, 研究対 象は液体へと次第にシフトした。当初の主なテーマは, 粘弾 性セグメントの意義と不均質系へ光学的手法の展開であった。

\section{3. 高分子の屈曲性と粘弾性セグメント}

\section{1 粘弾性セグメントの意義}

すでに述べたように，ガラス転移領域近傍の無定形高分子 の粘弾性は, MSORにより配向応力とガラス応力に分離する ことができる. 配向応力のずり弾性率の高周波数（短時間）極 限值 $E^{\prime}(\infty)$ から, 粘弾性セグメントのモル質量 $M_{\mathrm{S}}$ を定義で きる。

$$
M_{\mathrm{S}}=3 c R T / E^{\prime}(\infty)
$$

種々の高分子に対する測定から，バルク状態では粘弾性セグ メントは Kuhn セグメントと同程度の大きさであることわかっ た ${ }^{9)}$. エントロピー弾性の基本ユニットが Kuhn セグメント 程度であるということは，もっともらしく思えた，粘弾性セ グメントの測定は, 試料の分別等の必要がなく簡便にできる とメリットがあったが, その反面, Kuhn セグメントと同じで あれば粘弾性セグメントをあえて測定する意義もないように も感じた. しかしながら, 溶液とバルクでは Kuhn セグメン 卜の大きさは変わらないが, 粘弾性セグメントは溶液で大き くなることが次第に明らかになった ${ }^{10)}$. Fig. 2 に，ポリスチ レンの $M_{\mathrm{S}}$ の濃度依存性を示す。ポリスチレンの $M_{\mathrm{S}}$ はバル クでは $900 \mathrm{~g} / \mathrm{mol}$ 程度, 希薄溶液では $5000 \mathrm{~g} / \mathrm{mol}$ 程度になる。 一方, $C$ の值は変わらないので, 局所的な形態は変わってい ないと考えられる。原理的には， $M_{\mathrm{S}}$ は配向複屈折の高周波数 極限值から求めているので, バルク状態と希薄溶液で $M_{\mathrm{S}}$ が 異なる理由は，短時間域の配向度が溶液中では低下している ことを示す．したがって，局所的な変形におけるアフィン性 が, 溶液では崩れていると考えることができる. 別の表現と しては, 次のような解釈も可能である。散逸摇動定理による 


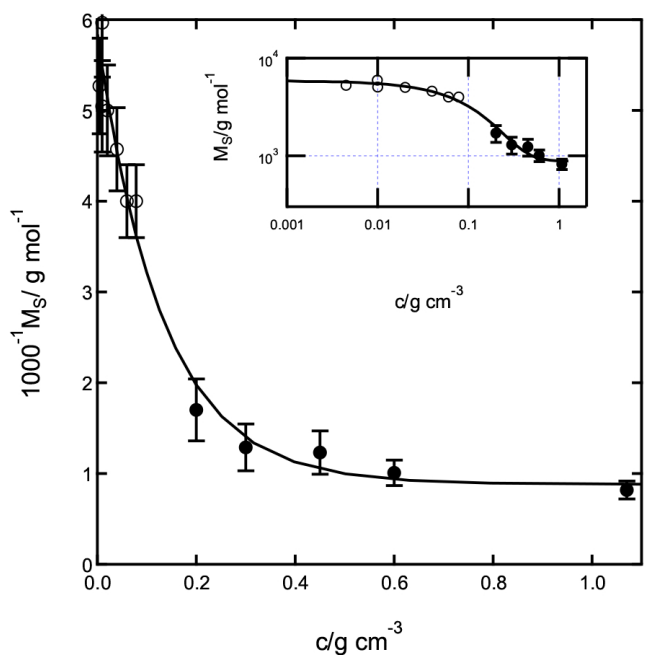

Fig. 2 Concentration dependence of viscoelastic segment of polystyrene in TCP. Reprinted with permission from Inoue T, Uematsu T, Osaki K, Macromolecules, 35, 820(2002). Copyright (2002) American Chemical Society.

と緩和弾性率は応力の時間摇らぎに関係付けられるから，短 時間領域の応力の摇らぎが喪失していること, つまり高次の Rouse モードが溶液中で喪失していること考えることもでき る ${ }^{11)}$. 高分子の形態変化は主鎖の回転によって生じるが, こ の運動は回転エネルギー障壁を持つために頻度が制限される. このため, ある一定の時間より速い配向緩和運動は, 溶液中 で制限をうけると考えることができる。

\section{2 分岐と粘弾性セグメント}

直鎖状高分子では，粘弾性セグメントは高分子鎖を粗視化 した運動単位として比較的容易に理解できる。ポリスチレン では，粘弾性セグメントはモノマー 8 個程度である ${ }^{4)}$ 。一方, 高分子鎖に分岐が密に入った場合には，粘弾性セグメントは どのように考えればよいであろうか. ポリマクロモノマーは, 繰り返し単位ごとに長い側鎖を持つ高分子である. Fig. 3 にポ リスチレンの例を示す ${ }^{8,12)}$. 枝鎖に比べ幹鎖が長い場合には, ボトルブラシ状になる。希薄溶液の研究から, 側鎖間の反発に より主鎖の剛直性が増加することが知られている。粘弾性セ グメントに対する分岐の効果を明らかにするために，バルク 状態でのポリマクロモノマーの粘弾性と複屈折について調べ た。その結果，枝鎖は通常とポリスチレンと同じく負の配向 複屈折を示すが, 幹鎖は正の配向複屈折を示すことが明らか になった。このことは，幹鎖は正の $C$ を持つこと意味し，幹 鎖の粘弾性セグメントを新たに定義できることが判明した， $C$ の值の違いから, 弾性率をガラス成分, 枝鎖成分, 幹鎖成分に 分離することができた。この結果を Fig. 4 に示す。ポリマクロ モノマーでは鎖の末端部が多いので，ガラス転移温度が低く なることを除けば，ガラス成分は直鎖と同等であった，枝鎖成 分の周波数依存性は, 枝鎖間に反発が働いているが, Rouse 型 のスペクトルを示した. 側鎖モードのコンプライアンスから, 共同運動性の範囲についても議論することができた，幹鎖成 分も Rouse 型のスペクトルを示した. ゴム状平坦領域が観測 されないのは，枝鎖が多いために幹鎖の濃度が低く，からみ 合いが生じないためである。幹鎖の弾性率の高周波数極限值

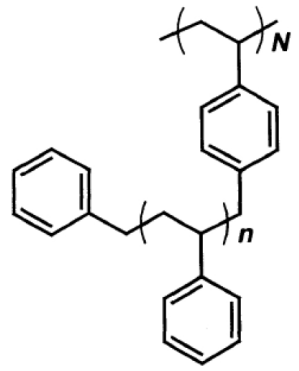

Fig. 3 Structure of poly(macromonomer) from styrene.

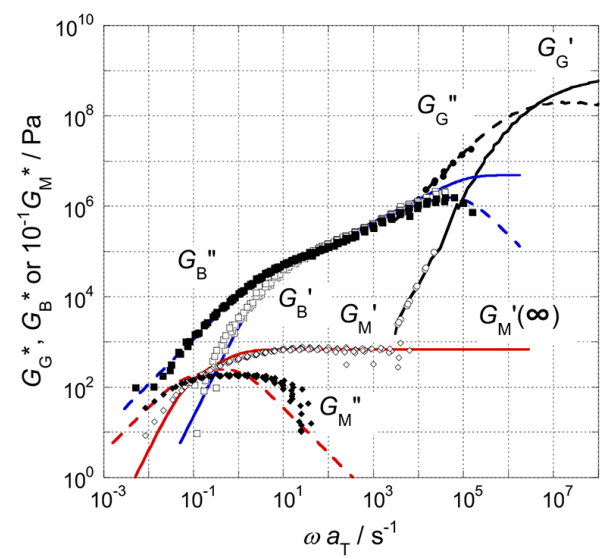

Fig. 4 Disassembly of complex modulus $G^{*}$ into component functions. From high frequencies, glassy, branch, and main chain components. Reprinted with permission from Iwawaki $\mathrm{H}$, Urakawa $\mathrm{O}$, Inoue $\mathrm{T}$, Nakamura Y, Macromolecules, 45, 4801(2012). Copyright (2012) American Chemical Society.

から，粘弾性セグメントのサイズを見積もると，七グメント サイズは直鎖にくらべて 10 倍程度大きくなった，Cは，応力 の保持ユニットを明確に反映するので, 複屈折を利用すれば 枝と幹のダイナミクスを分離して評価できることがわかった。

高密度の分岐は, 熱硬化性樹脂でも見られる. 熱硬化性樹 脂では耐熱性を向上させるために, 多数の架橋が導入される. このため粘弾性セグメントサイズ内にも分岐が生じる。この ような密な分岐による高分子ダイナミクスへの影響を調べる ために, 架橋度を系統的に変化させた熱硬化性樹脂について 測定を行った，架橋度の増加に伴い，ゴム状平坦部の弾性率 が増加するのに対し, 複屈折には架橋による変化がほとんど 現れないことがわかった ${ }^{13,14)}$ 。この結果は, 高度架橋系では 配向成分のみではゴム状平坦弾性率を記述することができず, セグメントの曲げや伸長による弾性が寄与することを意味す る。高度架橋系において詳細な解析を行うためには，セグメ ントの曲げや伸長モードの応力表式の必要性を痛感した.

\section{3 剛直な高分子の粘弾性}

セグメントの曲げや伸長モードの粘弾性への寄与は，半屈 曲性高分子の粘弾性の研究で明らかにされつつあった 15-17). こうしたセグメントの内部運動の観測には希薄溶液が適して いるが，一般的な屈曲性高分子では溶媒の運動に隠れて正確 
なことがわからない. しかしながら，主鎖の剛直性が増して Kuhn セグメントのサイズが大きくなれば, セグメントの内部 モードの観測が可能になることが期待できる。セルロースは 比較的硬い高分子として知られるが，難容性で特殊な溶媒に しか溶解しない。しかしながら，イオン液体に溶解すること が報告され, 我々も測定を行った ${ }^{18)}$ 。この研究では, 高周波 数領域で SOR の破れからセグメントの内部モードが存在する ことが観測できたが，七グメントサイズが十分に大きくない ため溶媒の寄与との分離が難しく, 内部モードを定量的に解 析することができなかった。 セルロース溶液に対する別の興 味は, セルロースのからみ合い点間分子量 $M_{\mathrm{e}}$ （からみ合いセ グメント) が小さく, バルク状態に外挿すると $M_{\mathrm{S}}$ より小さく なることが示唆されていた ${ }^{19)}$. 我々のセルロースやセルロー 又誘導体に対する測定結果では，バルク状態では $M_{\mathrm{e}}$ と $M_{\mathrm{S}}$ は 同程度であった ${ }^{18,20,21)}$ 。こうした $M_{\mathrm{e}}$ と $M_{\mathrm{S}}$ の比に対する興 味は，後述の “緻密からみ合い系”の研究へと繋がっていく.

より硬い高分子，すなわち半屈曲性高分子の粘弾性への興 味は, 上記の研究から自然に生まれた。持続長が長い高分子 の場合, 内部モードが観測されることは, 実験的に知られて いた 22-24)。当初は, 内部モードを曲げモードに帰属する試み が行われたが, 弾性率の周波数依存性をうまく説明できなかっ た。 その後，伸長モードでの説明が行われた ${ }^{17)}$. 持続長の 2 倍が Kuhn 長に対応するが, これはセグメント程度の長さの スケールでは，熱運動によりたわんだ構造をとることを意味 する。このため, セグメントの両末端間距離は, 熱運動の激 しさに応じて短くなる。このことは，たわんだ構造がバネの ように振る舞い，すなわちセグメント内部に伸長応力が生じ ることを意味する。末端間の張力の大きさは熱運動に由来す るので，エントロピー弾性の一種である。こうした考え方は, 2000 年頃に現れ，セグメントの内部モードが説明できるよう になった ${ }^{25)}$. しかしながら, 半屈曲性高分子の粘弾性の全容 解明には手がつけられていなかった。この理由は, 半屈曲性 高分子の多くが天然由来の水溶性高分子で, 粘弾性測定に適 した低揮発性の溶媒が知られていなかったためである. ポリ ヘキシルイソシアネートの希薄溶液の測定例 26) もあったが, アルクロールが使用できなくなったため, 追試すら困難になっ た。

セルロースの繰り返し単位の三つの水酸基を置換したセル ロース誘導体では, 主鎖の剛直性が増す。セルローストリス (フェニルカルバメート) CTC はその一例で, 溶液での広が りや粘度，さらに液晶形成能等がすでに調べられていた ${ }^{27)}$. CTCの持続長はポリスチレンより 5 倍くらい長いことがわかっ ていたが，粘弾性はほとんど検討されていなかった。しかし ながら, CTCが粘弾性測定に適したリン酸トリクレジル TCP に溶解することが見出された ${ }^{28)}$. 複屈折は配向モードを検出 し, 曲げモードや伸長モードには鈍感である。このため, 複 屈折と粘弾性測定を組み合わせると, 配向モードと曲げモー ド／伸長モードと定量的に分離することができる. Fig. 5 に測 定の一例を示す。 $K^{\prime}(\omega) C^{-1}$ は, 複屈折測定から求めた弾性率 の配向成分 $G_{\text {link }}^{\prime}(\omega)$ を示す. $G^{*}$ は, 溶媒の寄与 $G_{\mathrm{sol}}^{\prime}(\omega)$ と配 向成分 $G_{\text {link }}^{\prime}(\omega)$ のみでは記述できず, セグメントの内部モー ド（伸長成分） $G_{\text {tens }}^{\prime}(\omega)$ が明瞭に存在することがわかる.

CTC 溶液では, 高濃度域でからみ合いセグメントが持続長 より短くなり, “緻密からみ合い系 (tightly entangled system)” が実現できる可能性がある。実際に試してみると, 液晶転移

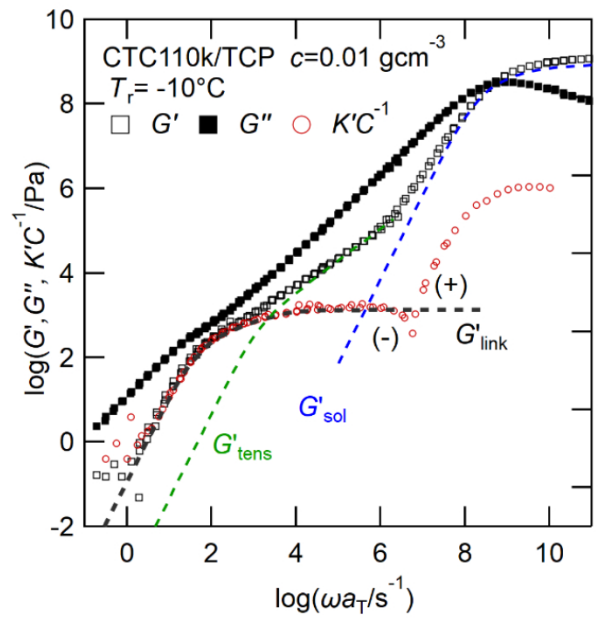

Fig. $5 G^{\prime}, G^{\prime \prime}$, and $K^{\prime}$ divided by stress-optical coefficient $\left(K^{\prime} C^{-1}\right)$ for CTC110k $0.01 \mathrm{~g} \mathrm{~cm}^{-3}$ solution. Reference temperature is $-10^{\circ} \mathrm{C}$. Three broken lines represent $G_{\text {sol }}^{\prime}$ (blue), $G_{\text {link }}^{\prime}$ obtained by fitting $K^{\prime} C^{-1}$ (black), and $G_{\text {tens }}^{\prime}$ obtained from analysis using SOR(green). Reprinted with permission from Okada Y, Goto Y, Tanaka R, Katashima T, Jiang XY, Terao K, Sato T, Inoue T, Macromolecules, 51, 9626(2018). Copyright (2018) American Chemical Society.

濃度より低濃度で限られた濃度域範囲ではあるが緻密からみ 合い系を実現できることがわかった，粘弾性の測定例を Fig. 6 に示す 29)。弾性率を見ると, 通常のからみ合い系の粘弾性ス ペクトルと大差はない.しかしながら，複屈折を測定して比べ てみると，通常のからみ合い系ではガラスゴム転移領域の低 周波数領域から流動領域までSOR が成立するのに対し, 緻密 からみ合い系ではゴム状平坦領域でも SOR が成立せず，この 領域で別の緩和モードが寄与することがわかる。ささらに，複 屈折の緩和には, Rouse モードが観測されない. このように, 弾性率には配向緩和モードに加えて, セグメントの曲げモー ドが関与していることがわかる．Fig. 7 には，弾性率を配向緩 和, 曲げ, 伸長モードに分離した結果を示す. 配向緩和モード は, からみ合い高分子のゴム状平坦部の緩和モードに極めて 類似している。緻密からみ合い系においても，レプテーショ ン型の配向緩和を示していることがわかる。曲げモードのス ペクトルは, Rouse モードに近い. セグメントの曲げは, 局 所的な応力であるので, 束縛解放運動によって緩和しやすい ことがうかがえる。伸長モードは, $\omega^{3 / 4}$ に比例し, 希薄域と 共通である。

こうした半屈曲性高分子の研究は, セルロースナノファイ バー CNFへの展開が期待できる. CNF は植物細胞壁やパル プ繊維をナノサイズまで機械的に解繊したナノセルロースの 一種で, プラスチックの補強繊維などとしての使用が期待さ れている. CNFのキャラクタリゼーションの方法として, 粘 弾性測定が期待されている。しかしながら, CNF 希薄溶液の 粘弾性スペクトルは, 幅広い緩和時間分布を示し, 特徴的な 緩和時間を見いだすことができず解析が困難であった。最近， 我々のグループでは, 幅広い緩和時間分布の原因が CNF の長 さ分布に加えて，伸長モードが原因であることを見出した。一 方, 複屈折は配向緩和を強く反映するので, $K^{*}(\omega)$ のデータは 剛直棒の理論を用いて解析が可能で, CNF の長さや長さ分布 を求めることができることがわかった，さらに，この長さの デー夕に伸長モードを考慮することで, CNF 溶液の粘弾性緩 


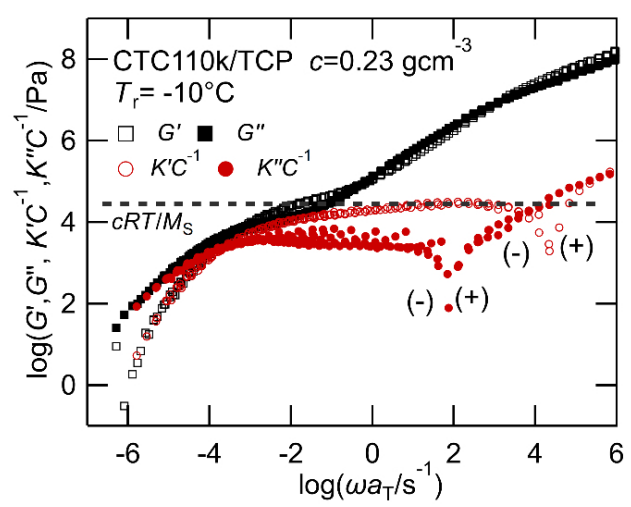

Fig. 6 Complex modulus and complex strain-optical coefficient for a tightly entangled CTC/TCP solution. Reprinted with permission from Okada Y, Goto Y, Tanaka R, Katashima T, Jiang XY, Terao K, Sato T, Inoue T, Macromolecules, 51, 9626(2018). Copyright (2018) American Chemical Society.

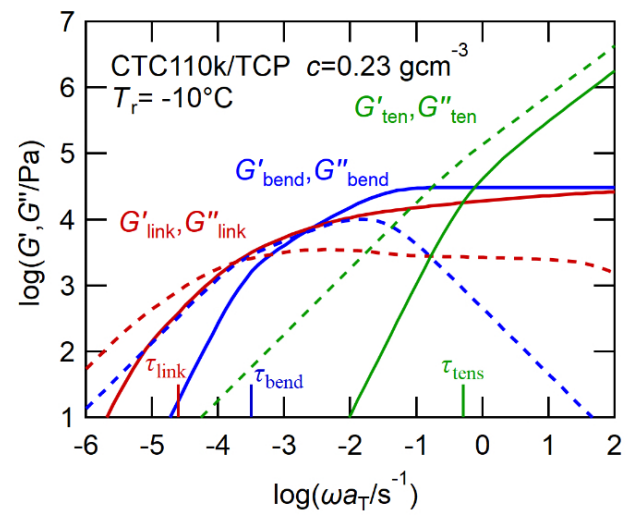

Fig. 7 Disassembly of complex modulus into tension, bend, and link orientation components. Reprinted with permission from Okada Y, Goto Y, Tanaka R, Katashima T, Jiang XY, Terao K, Sato T, Inoue T, Macromolecules, 51, 9626(2018). Copyright (2018) American Chemical Society.

和が解析できるようになった，さらに伸長モードから，CNF の持続長と曲げ剛性を評価できることがわかった。 なお，CNF の長さは $1 \mu \mathrm{m}$ 程度になるので, 希薄域での測定を行うために は，極低濃度 $(0.01 \%)$ での測定が必要になり，高感度の複 屈折測定装置が必要になる。我々のグループでは，共軸円筒 型の複屈折測定装置を新たに開発した ${ }^{30)}$.

\section{4. 不均質系の修正応力光学則}

複屈折測定では, 光を使うので対象は透明な物質に限られ る。しかしながら，不均質系 (分散系)でも粒子とマトリック スの屈折率のマッチングなどを行えば，透明な物質となり複 屈折測定が可能になる。分散系での興味は, 応力表式と応力 光学則の妥当性である。粒子が小さいと, ブラウン運動由来 の応力が観測される ${ }^{31)}$. 理論的には, ブラウン運動由来の応 力は, 粒子の相対配置の異方性によって表され, 配置の異方 性は複屈折や二色性として観測可能で, 応力光学則の成立が 予測されていたが, 実験は定常流での測定のみで緩和過程で 成立する（同じ緩和時間分布を持つか）かは未確認であった。
我々もシリカ粒子分散系について光学測定を行った：シリカ 粒子分散系では, 分散性向上のためにシリカ粒子と屈折率が 近い溶媒が用いられ，光学的な測定が可能である．測定の結 果，ブラウン運動に由来するモードに加えて，別のモードが 見つかった ${ }^{32)}$ 。このモードは，凝集体によるものと推定した が, この研究から不均一系の応力表式に興味が生まれ, 次に 述べる修正応力光学則による不均一系の各相の部分応力の評 価へと繋がった。

\section{1 シリカ粒子補強ゴム}

分散系の研究を行う場合, 溶液では粒子が小さいとブラウ ン運動により粒子の再配列が生じる。この効果をどのように 取り入れるかは厄介な問題で，実験的な検証もしにくい，再配 列による流体力学的相互作用の変化と, ブラウン運動による 弾性を分離することは容易ではない，マトリックスが弾性体 である場合には，この問題を回避できる。こうした観点から 行った不均質系の研究事例として、ゴムにシリカ微粒子を分 散させた場合について述べる。ゴムとしてスチレンブタジエ ンゴムSBRを用い，ブタジエンの分率を調整するとシリカ粒 子と屈折率を合わせることができ, 複屈折測定が可能な透明 な試料が得られる。この系に対して複屈折測定を行うと, シ リカ粒子由来の複屈折は弱く無視できるので, マトリックス 高分子による相応力を評価することができる， $G^{*}(\omega)$ と $K^{*}(\omega)$ の測定結果を Fig. 8 に示す ${ }^{33)}$. 以下の議論では，補強効果と して弾性率の増加率 $G / G_{0}$ を考える。ここで, $G_{0}$ と $G$ はそ れぞれ補強粒子添加前後の弾性率である. Fig. 8 の上図を見 ると, シリカ粒子の充填によって $G^{*}(\omega)$ は増加するが, $K^{*}(\omega)$ はほとんど変化しないことがわかる。 $K^{*}(\omega)$ は, マトリック 入高分子の保持する応力のみを反映するから， $K^{*}(\omega)$ が変化 しないことは粒子の充填によってマトリックス高分子の保持 する応力が変わらないことを示している．粒子の充填によっ てマトリックス高分子の体積は減っているから，この減少分 とマトリックス高分子へのひずみの集中とがうまく相殺され ていることがわかる。すすなわ，シリカ粒子の体積分率を $\phi$ とすると, マトリックス高分子の体積分率は $1-\phi$ であるか ら，マトリックス高分子へのひずみの集中が $1 /(1-\phi)$ 程度で あることを意味する，マトリックス高分子が保持する応力が 変わらないのに, $G^{*}(\omega)$ に顕著な補強効果が観測されるのは, 粒子が大きな応力を保持しているためである。ゴムの補強効 果の説明では，Guth-Goldの考え方をよく目にするが，この考 え方では弾性率の増加をすべてマトリックス高分子の実効歪 みの増加として説明している。 この考え方では, 粒子は応力 を保持しないことになる，本研究結果は，こうした考え方が 誤りであることを明確に示すものである.

今日では複合材料等の弾性体の補強効果は, マイクロメ カニックス理論を用いて議論される. 球状粒子の場合には, Eshelby/Mori-Tanaka 理論 ${ }^{34,35)}$ がよく知られている. マイク ロメカニックスの理論では, 不均質系に拀いて成分 $i$ の平均応 力（相応力） $\sigma_{i}$ と平均ひずみ $\gamma_{i}$ を考える.ささらに、ひずみと 応力のそれぞれに対して，加成性を考える。したがって，補 強粒子を $\mathrm{F}$ ，マトリックスを $\mathrm{M}$ とすると次式のように書ける。

$$
\begin{aligned}
\gamma & =(1-\phi) \gamma_{\mathrm{M}}+\phi \gamma_{\mathrm{F}} \\
\sigma & =(1-\phi) \sigma_{\mathrm{M}}+\phi \sigma_{\mathrm{F}}
\end{aligned}
$$



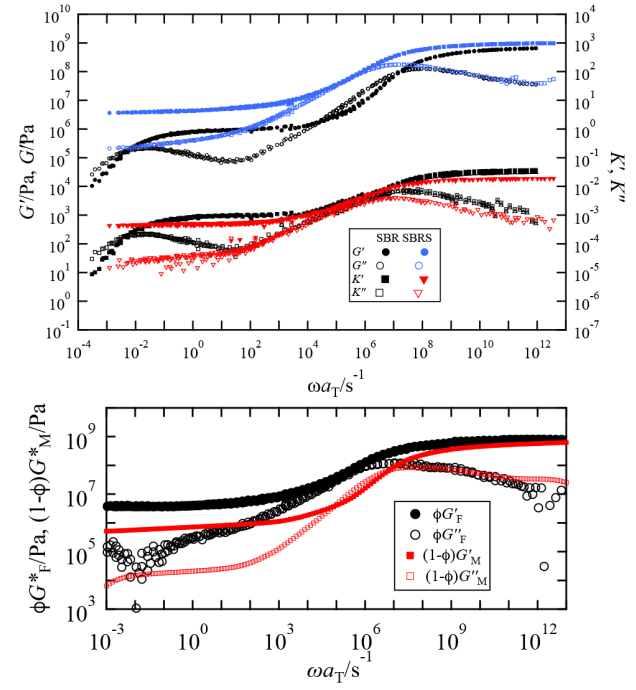

Fig. 8 Upper panel: $G^{*}$ and $K^{*}$ for the filled and vulcanized SBR and neat SBR. $K^{*}$ reflects birefringence of matrix rubber. A significant reinforcement effect is observed for $G^{*}$ while for $K^{*}$ no clear difference before and after filling. This result indicates that the strain amplification factor for matrix rubber is $(1-\phi)$, where $\phi$ is the volume fraction of the filler. Lower panel: Decomposition of modulus into Matrix and Filler components. Frequency dependence of the two components are close to each other, indicating the proportionality between $G_{\mathrm{F}}$ and $G_{\mathrm{M}}$. Reprinted with permission from Inoue T, Narihisa Y, Katashima T, Kawasaki S, Tada T, Macromolecules, 50, 8072(2017). Copyright (2017) American Chemical Society.

レオロジーの分野では，不均質系の弾性率の計算においては 高柳モデル 36) が有名で，二つの物質を直列あるいは並列に力 学的に結合させたモデルがよく紹介される。これらのモデル では，それぞれひずみと応力のどちらか一方のみに加成性が 成立する。マイクロメカニックスの理論では，ひずみと応力 の加成性を連立させて解く. 粒子が固い場合には, 粒子のひ ずみ $\gamma_{\mathrm{F}}=0$ となるから， $\gamma_{\mathrm{M}}=\gamma /(1-\phi)$ が得られる.さらに, Eshelby/Mori-Tanaka 理論では, 非圧縮性媒体に固い球状粒子 を分散させた場合には $\sigma_{\mathrm{F}}=2.5 \sigma_{\mathrm{M}}$ を与える.したがって, 次 式が得られる。

$$
G / G_{\mathrm{M}}=(1-\phi) /(1-\phi)+2.5 \phi /(1-\phi)
$$

右辺第 1 項はマトリックスからの寄与, 第 2 項は粒子のからの 寄与を表す。マトリックス高分子がガラス状になる領域では, 粒子とマトリックスの弾性率の差が小さくなり, 両者の弾性 率を陽に含む式になる. Fig. 8 の下図に示すように, 粒子相と マトリックス相の弾性率の周波数依存性は似ている。これは, 粒子の応力がマトリックスの応力を比例的に増強したもので あることを示している. 比例係数が周波数によって一定でな いのは, 粒子の弾性率が有限でゴム状領域では固い粒子とみ なせるが, ガラス状領域ではマトリックスとの力学的なコン トラストが減ってしまうためである（弾性率が同じであれば 補強効果は発現しない)。ここでは示さないが, 本研究で得ら れたガラス状態での補強効果 $G / G_{0}$ は, Eshelby/Mori-Tanaka 理論と矛盾しない33).

一方，ゴム状態では補強効果は Eshelby/Mori-Tanaka 理論と 一致せず，粒子の実効体積が増えていることが示唆された。

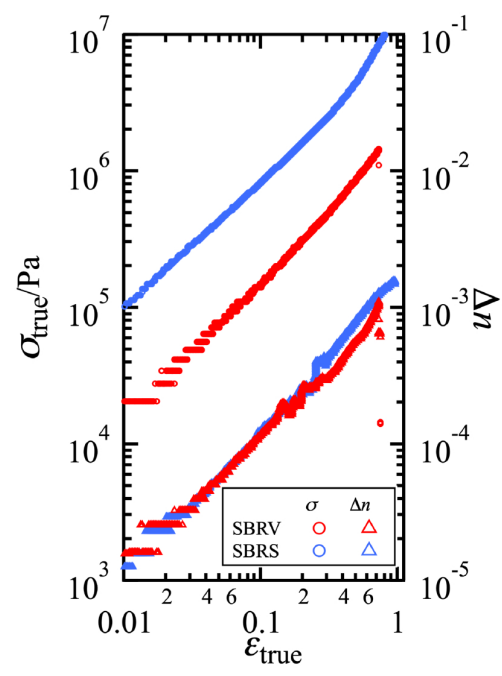

Fig. 9 Stress and birefringence growth of the unfilled (red) and the filled rubber (blue) during tensile elongation. Reprinted with permission from Inoue T, Narihisa Y, Katashima T, Kawasaki S, Tada T, Macromolecules, 50, 8072(2017). Copyright (2017) American Chemical Society.

DSC 測定から，ガラス転移に関わる高分子の体積が減少して いることがわかり, シリカ粒子表面近傍で $2 \mathrm{~nm}$ 程度のガラス 化した高分子層を考慮すべきことが明らかになった。このガ ラス化した高分子は, マトリックス高分子がガラス化すると 区別できないが，ゴム状領域では有効な補強効果をもたらす と考えられる

粒子の分散状態が補強効果にどのような影響を与えるかは, 興味ある問題である。このため, 前出の試料について大変形 1 軸伸長実験を行った。この結果を Fig. 9 に示す. 縦軸は真応 力 $\sigma_{\text {true }}$, 横軸は伸長比を $\lambda$ とすると Hecky ひずみ $\epsilon_{\text {true }}=\ln \lambda$ である，応力は補強粒子の添加によって，ひずみ量によらず 約 7 倍ほど大きくなっている. また, 複屈折に変化が現れな

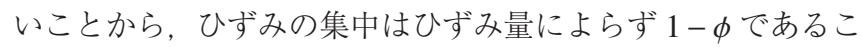
とがわかる。このように補強効果にはひずみ依存性が現れな いことがわかった，このことは，粒子の相対位置は補強効果 に影響しないことを意味する。この結果は粒子の分散性がよ いことに対応し, 前述の理論との一致とも矛盾しない. 以上 の結果から, 補強粒子が均質に分散している場合には, 弾性 率には非線形（ひずみ依存性）が現れないと考えることがで きる。一方, 粒子の凝集が生じるとマトリックス高分子を含 んだ凝集体を形成し, 実効的な体積分率を増加させ, 補強効 果を強めることが容易に想像できる，粒子の凝集体には，粒 子の表面のガラス化した高分子層も関与し, 粒子の凝集体に ガラスによる塑性的な応答をもたらすことが推測できる。こ のため, 大変形に対してひずみ依存性や履歴の効果を示すよ うになると説明できる。こうした大変形に対するひずみ依存 性や履歴の効果は, Payne 効果 ${ }^{37)}$ や Mullins 効果 ${ }^{38,39)}$ とし て知られている。

\section{2 ジブロック共重合体溶液}

不均質溶液のレオロジーにおける粒子の硬さや粒子の配列 の効果を調べるために, ジブロック共重合体溶液について調べ 
た ${ }^{40,41)}$ 。ここで述べる研究で用いた試料は，スチレンブタジ エンジブロック共重合体 SB のテトラデカン C14 溶液である. この系は, C14 がスチレンブロックに貧溶媒, ブタジエンに 良溶媒のため, スチレンがコアブタジエンがコロナとなった 球状ミセルを形成する。条件により球状ミセルが格子状に配 列し，これに伴い塑性を示すようになる。この溶液の複素弾 性率と複素ひずみ光学係数を, Fig. 10 に示す ${ }^{41)}$. 複素弾性率 を見る限り, 高周波数域 $\left(\omega>10 \mathrm{~s}^{-1}\right)$ に緩和がわずかに認め られるが，弾性的な応答を示している，測定試料は溶液で大 変形では流動するから, 塑性体である. 一方, 複素ひずみ光学 係数には, 符号の反転を含む複雑な緩和が認められた，符号 の反転は, 符号の異なる緩和モードが存在すること, すなわ ち複数の応力の発生機構が存在することを示している. 応力

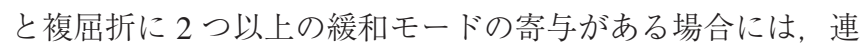
立方程式を解くことができず, 各モードを定量的に求めるこ とはできない。 そこで, 複数の単一緩和型のモードを用いて フイッティングを行ったところ, 応力光学係数の異なる 4 つの 緩和モードで, $G^{*}(\omega)$ と $K^{*}(\omega)$ を矛盾なく表すことができた.

$$
\begin{aligned}
& G^{*}(\omega)=G_{1}^{*}(\omega)+G_{2}^{*}(\omega)+G_{3}^{*}(\omega)+G_{4}^{*}(\omega) \\
& K^{*}(\omega)=C_{1} G_{1}^{*}(\omega)+C_{2} G_{2}^{*}(\omega)+C_{3} G_{3}^{*}(\omega)+C_{4} G_{4}^{*}(\omega)
\end{aligned}
$$

これらの 4 つのモードは, 応力光学係数の符号と值から考え て, 高周波域から, コアの配向応力 (相応力), マトリックス の配向応力 (相応力), コアの変形, ミセルの格子の変形に 由来するものと考えられた．格子の変形に由来する複屈折は, 本研究ではじめて観測されたものである. 当時は, 4つのモー ドに分解することで精一杯であったが, 今思うとマイクロメ カニックス理論を用いればより定量的な議論が可能であった. コアの変形による応力は, Palierne 理論 42) で扱われる界面張 力の効果と考えて良いであろう。こうした理論の適用におい ては, 従来の研究では総応力のみが計算されてきたが, 複屈 折測定を利用することで成分応力の推定が可能になり，より 詳細な検討が可能になると考えられる.

\section{3 流動誘起構造}

ひも状水溶液やある種の混合液体では, 強い流動を加えると shear band や相分離などの流動誘起構造が観測される.こうし た構造の観測や応力の分布状態の観測にも複屈折測定は有用 である，我々のグループでは，偏光イメージングカメラを利用 した流動の可視化装置を開発した ${ }^{43)}$. 一般に複屈折の観測は, クロスニコル下で行われることが多いが, リターデーションと 消光角を透過光強度から同時に決定するためには, 偏光の変 調など特別な工夫が必要である. 偏光イメージングカメラは, 画素ごとに透過軸の異なる偏光子を配置したもので, 透過軸 の異なる 4 画素の強度を比較することによって, リターデー ションと消光角を同時に測定できる，応答が高速なので，過 渡現象の複屈折の観測に適している. 紙面の都合上詳細は述 ベないが, この装置のよりひも状ミセル溶液の vorticity band の形成と粘弾性パラメーターの関係について検討を行った ${ }^{44)}$.
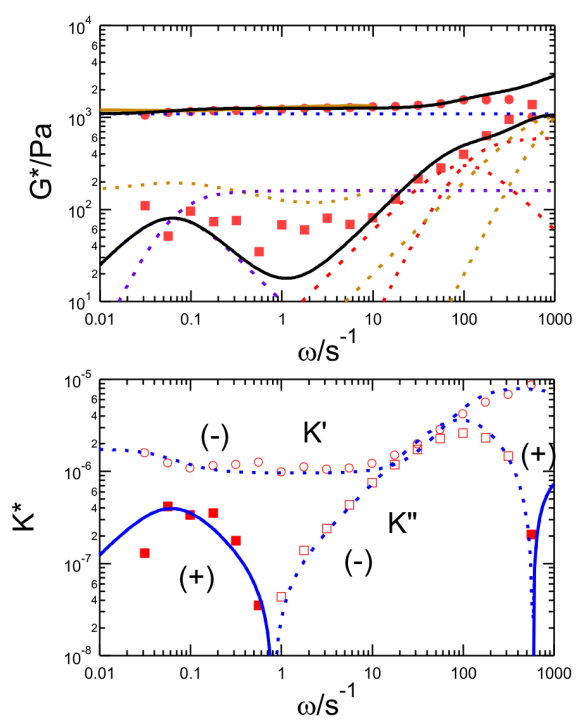

Fig. 10 Upper panel: Frequency dependences of storage and loss moduli, $G^{\prime}$ and $G^{\prime \prime}$, measured for SB-C14(19.1) at $T_{\mathrm{r}}=30^{\circ} \mathrm{C}$. Thick curves show the results of fitting with the four Maxwellian modes. Thin curves represent frequency dependence for each Maxwellian mode. Lower panel: Frequency dependence of $K^{*}$ calculated as $C G^{*}$ for SB-C14(19.1) at $T=30^{\circ} \mathrm{C}$. Curves show the results of fitting with the four Maxwellian modes. Reprinted with permission from Tamura E, Kawai Y, Inoue T, Watanabe H, Macromolecules, 45, 6580(2012). Copyright (2012) American Chemical Society.

\section{5. 結 言}

本稿では，著者が大阪大学に異動後に開発したずり型の複 屈折装置を利用した研究を中心に概説した。複屈折は応力と 高い親和性を持ち, 両者の緩和を比べれば応力の起源を探る 有用な指標になる。通常の非晶性高分子のバルク状態では, セ グメントの配向による応力とガラス性に起因する応力が重要 である，まず，配向応力から求めることができる粘弾性セグ メントについて説明し，Kuhn セグメントとの違い，またその 大きさと分岐の効果について述べた.さらに粘弾性セグメン トの内部モードについて触れ, 内部モードがセグメントサイ ズを決定する鎖の剛性と関係付けられることを述べた．特に， 現在の解釈では内部モードはエネルギー弾性ではなく, 熱運 動に由来するエントロピー弾性であることに注意が必要であ る. セグメントの内部モードは, 半屈曲性高分子で重要にな る。からみ合いセグメントが粘弾性セグメントより小さくな る緻密からみ合い系では, 屈曲性高分子と類似のゴム状平坦 領域が粘弾性スペクトルに観測されるが，その起源は配向モー ドと曲げモードの両者の寄与があることを応力光学則の破れ から示した，緻密からみ合い系の研究例は，アクチン等の研 究例が一部存在するものの, 詳細な検討例がなく今後の展開 が望まれる。このためには，粘弾性実験に適した溶液系の開 発が不可欠である。CNF 溶液も高濃度では緻密からみ合い系 となり，実用的にも重要な課題である。

さらに本稿では, 複屈折測定を不均質系に展開する方法に ついて述べた。ここでは，相応力と相ひずみという考え方を紹 介し, 複屈折測定から相応力が求められることを示した. この 知見は, 材料の補強効果を考える上で重要な知見である. 誘電 率，熱膨張率なども同様の考えで説明できる現象であり，こう 
した物性への理解にも有用である。さらに不均質系では，各 相の相応力に加え, 界面張力, 粒子のブラウン運動, 粒子間 相互作用による応力が観測され，これらの定量的な分離・評 価に複屈折測定は有用である。不均質系には，ゲル粒子分散 系, エマルションなど興味深い系が多数あり, 今後, これら の系への適用を視野にいれて研究を進めたいと考えている.

以上をまとめると, 複屈折と応力を比較検討すれば, 応力 の起源に応じた分離が可能になり．マクロなレオロジー現象 を微視的に理解することを目的とする分子レオロジーの研究 手法として有用な知見を与えてくれる.

\section{謝 辞}

レオロジー研究における複屈折測定の有効性をご教示頂い た。尾崎邦宏京都大学名誉教授に深く感謝いたします。ずり型 複屈折測定装置の開発にあたっては, 故野村春治京都工芸繊維 大学名誉教授にご支援いただいた。ポリマクロモノマーは中 村洋京都大学教授, セルロースおよびセルロース誘導体は佐 藤尚弘大阪大学教授並びに寺尾憲大阪大学准教授, セルロー スナノファイバーは森林総合研究所田仲玲奈博士との共同研 究である。 また, 分散系の分子レオロジーについては, 渡辺 宏京都大学教授に有益なご議論をいただいた。補強ゴムの研 究は, 多田俊生博士 (住友ゴム工業 (株)）との共同研究であ る. 研究の遂行にあたっては, 岩脇寛博士（住友化学（株））, 馬路哲博士（住友ベークライト（株）），田村英子博士（花王 (株)），大場矢登博士（住友化学 (株)），岡田佑樹博士（積 水化学工業 (株)）に, 特にご尽力いただいた。ここに記して, 深く謝意を表します.

\section{REFERENCES}

1) Janeschitz-Kriegl H, Polymer Melt Rheology and Flow Birefringence, Springer-Verlag, Berlin (1983).

2) Flory PJ, Statistical Mechanics of Chain Molecules, John Wiley and Sons, New York (1969).

3) Doi M, Edwards SF, The Theory of Polymer Dynamics, Clarendon, Oxford (1986)

4) Inoue $\mathrm{T}$, Okamoto $\mathrm{H}$, Osaki $\mathrm{K}$, Macromolecules, 24, 5670 (1991).

5) Inoue $\mathrm{T}$, Hayashihara $\mathrm{H}$, Okamoto $\mathrm{H}$, Osaki K, Nihon Reoroji Gakkaishi, 19, 220 (1991).

6) Roland CM, Mott PH, Macromolecules, 32, 4728 (1999).

7) Hayashi C, Inoue T, Nihon Reoroji Gakkaishi, 37, 205 (2009).

8) Iwawaki H, Inoue T, Nakamura Y, Macromolecules, 44, 5414 (2011).

9) Inoue T, Osaki K, Macromolecules, 29, 1595 (1996).

10) Inoue T, Uematsu T, Osaki K, Macromolecules, 35, 820 (2002).

11) Larson RG, Macromolecules, 37, 5110 (2004).
12) Iwawaki $H$, Urakawa $O$, Inoue $T$, Nakamura $Y$, Macromolecules, 45, 4801 (2012).

13) Maji S, Urakawa O, Inoue T, Polymer Journal, 46, 584 (2014).

14) Maji S, Urakawa O, Inoue T, Polymer Journal, 46, 272 (2014).

15) Morse DC, Macromolecules, 31, 7030 (1998).

16) Morse DC, Macromolecules, 31, 7044 (1998).

17) Shankar V, Pasquali M, Morse DC, Journal of Rheology, 46, 1111 (2002).

18) Maeda A, Inoue T, Sato T, Macromolecules, 46, 7118 (2013).

19) Matsumoto T, Tatsumi D, Tamai N, Takaki T, Cellulose, 8, 275 (2001).

20) Maeda A, Inoue T, Nihon Reoroji Gakkaishi, 39, 159 (2011).

21) Maeda A, Inoue T, Yamaguchi M, Polumer Journal, 46, 149 (2014).

22) Warren TC, Schrag JL, Ferry JD, Biopolymers, 12, 1905 (1973).

23) Amis EJ, Carriere CJ, Ferry JD, Veis A, International Journal Of Biological Macromolecules, 7, 130 (1985).

24) Carriere CJ, Amis EJ, Schrag JL, Ferry JD, Macromolecules, 18, 2019 (1985).

25) BroedersCP MF, Rev Mod Phys, 86, 995 (2016).

26) Nemoto N, Schrag JL, Ferry JD, Polym. J., 7, 195 (1975).

27) Sato T, Shimizu T, Kasabo F, Macromolecules, 36, 2939 (2003).

28) Jiang X, Sato T, Terao K, Polymer Bulletin, 75, 1265 (2018).

29) Okada Y, Goto Y, Tanaka R, Katashima T, Jiang XY, Terao K, Sato T, Inoue T, Macromolecules, 51, 9626 (2018).

30) Tanaka R, LS, Kashiwagi Y, Inoue T, Journal of Scoeity of Rheology, Japan, 46, 221 (2018).

31) Shikata T, Pearson DS, Journal of Rheology, 38, 601 (1994).

32) Kawai $Y$, Tamura E, Shikata $T$, Inoue $T$, Journal of society of rheology, Japan, 40, 79 (2012).

33) Inoue T, Narihisa Y, Katashima T, Kawasaki S, Tada T, Macromolecules, 50, 8072 (2017).

34) Eshelby JD, Proc. Roy. Soc. Lond.,, A241, 376 (1957).

35) Mori T, Tanaka K, Acta Metallurgica, 21, 571574 (1973).

36) Takayanagi M, Uemura S, Minami S, J. Polym. Sci. C5 113 (1964).

37) Payne AR, J. Appl. Polym. Sci., 9, 1073 (1965).

38) Mullins L, Rubber Chem. Technol., 21, 281 (1948).

39) Mullins L, Tobin N, Rubber Chem. Technol., 30, 555 (1957).

40) Tamura E, Kawai Y, Inoue T, Matsushita A, Okamoto S, Soft Matter, 8, 6161 (2012).

41) Tamura E, Kawai Y, Inoue T, Watanabe H, Macromolecules, 45, 6580 (2012).

42) Palierne JF, Rheologica Acta, 29, 204 (1990).

43) Oba N, Inoue T, Rheologica Acta, 55, 699 (2016).

44) Oba N, Inoue T, Nihon Reoroji Gakkaishi, 46, 93 (2018). 